\title{
FREQUENCY ANALYSIS OF MEDICINAL PRESCRIPTS AT PHARMACOTHERAPY OF BRONCHIAL ASTHMA IN CHILDREN
}

\author{
Iryna Kostiuk \\ Department of Organization and Economics of Pharmacy \\ O. O. Bogomolets National Medical University \\ 13 Shevchenko blvd., Kyiv, Ukraine, 01601 \\ iryna.kostuk@ukr.net \\ Olha Dziuba \\ Kyiv City Children's Clinical Hospital No. 2 \\ 3 Alishera Navoi ave., Kyiv, Ukraine, 02125 \\ Mikola Makukha \\ Kyiv City Children's Clinical Hospital No. 2 \\ 3 Alishera Navoi ave., Kyiv, Ukraine, 02125 \\ Larisa Golopikho \\ Department of Clinical Pharmacology and Clinical Pharmacy \\ O. O. Bogomolets National Medical University \\ 13 Shevchenko blvd., Kyiv, Ukraine, 01601
}

\begin{abstract}
Today, bronchial asthma is the most widespread childhood chronic respiratory disease in the world. To make managerial decisions in the health care system of Ukraine and to identify priority areas for the response to this disease, it is necessary to carry out a quantitative analysis of the appointment letters and the proportion of patients who received specific drugs for determining the main areas of therapy.

Aim. Carrying out of frequency analysis of medical prescriptions at pharmacotherapy of bronchial asthma in children.

Materials and methods. 574 medical cards of an indoor patient with the main diagnosis of "Bronchial asthma", received at the Kyiv City Children's Clinical Hospital No. 2. A retrospective frequency analysis of the prescribing of drugs for archival data of appointment letters was conducted.

Results. The conducted analysis of patients by age and sex allowed to establish the correspondence of the obtained results with the results of previous scientific studies on gender differences in the prevalence of bronchial asthma in children. In $45.3 \%$ of the children, the length of stay was 2-10 days, and in 37.3\% - 11-20 days, indicating a sufficiently long period of inpatient treatment. According to the letters of appointment in the medical records of the inpatient patient, the physicians carried out 1983 appointments, of which 1867 were medicated $(94.2 \%)$, and 116 were non-medicated methods (5.8\%). The medical appointments of doctors included 1763 medicines. Of these, $94.4 \%$ are medicines belonging to 11 groups according to ATC classification, $1.5 \%$ - solutions for washing, irrigation, treatment, $0.3 \%$ - dietary supplements, $0.1 \%$ - homeopathic preparations, $3.7 \%$ - other. The data that was obtained when calculating the intensity of the target varies in the range of 0.0006 to 0.07 . The highest rates had only 2 drugs - Ventolin nebuli and Pulmicort, which were available in $22.3 \%$ and $23.0 \%$ of the patient's medical cards respectively, that is, every fifth patient. It was found that the ratio of drugs of domestic and foreign manufacture is $34.2 \%$ (20 pharmaceutical companies) and $65.8 \%$ (25 producing countries), respectively.

Conclusions. The received data of the conducted analysis of prescriptions of medicinal products allow establishing a significant nomenclature of medical appointments for children with bronchial asthma. The promising direction for domestic pharmaceutical companies in the production of drugs for the treatment of the examined nosology was revealed. At the same time, the frequency analysis of the nomenclature of drugs can be used in the selection of drugs for reimbursement programs and medical insurance after further pharmacoeconomic studies.
\end{abstract}

Keywords: bronchial asthma in children, pharmacotherapy, nomenclature of medicinal products, medicinal products. 


\section{Introduction}

Today, bronchial asthma (BA) is the most widespread childhood chronic respiratory disease in the world. According to the prevalence, severity and insufficient diagnostic criteria, the disease is a "disease of the century", since it requires significant expenses for pharmacotherapy, emergency and inpatient care, rehabilitation, and also reduces the quality of life of children and their families [1, 2].

The average annual cost of asthma treatment is quite high and for one child it is $€ 929.35$, of which $€ 698.65$ is a direct expense and $€ 230.70$ indirect. However, in children with partially controlled or uncontrolled BA, the average cost per year is significantly higher. The study of the very economic aspects of BA pharmacotherapy is relevant for the adoption of management decisions in the health care system of Ukraine and in determining priority areas for the response to this disease $[3,4]$.

The urgency of this issue is indicated in a number of normative legal documents. Thus, the main areas of development of the pharmaceutical industry are to increase the level of population provision with effective, safe and high-quality drugs for affordable pharmacotherapy, which is specified in the Law of Ukraine "Fundamentals of the legislation of Ukraine on health" and in the Concept of development of the pharmaceutical sector of the health care sector of Ukraine for 2011-2020[5, 6].

In connection with the foregoing for this nosology, it is necessary to carry out a quantitative analysis of the appointment letters and the proportion of patients who received specific drugs to determine the main areas of therapy. There is also a need to identify leaders among drugs which are preferred by doctors, since the quality of diagnosis and treatment of asthma still needs to be improved.

In a number of analyzed publications in recent years, the issues of clinical and economic analysis of the pharmaceutical supply of various diseases, such as gynecological diseases [7], ischemic heart disease [8], lumbar ischialgia [9], metabolic syndrome [10], tonsillitis [11], chronic cholecystitis [12]. Special attention was devoted to such researches of children's diseases, namely viral diarrhea [13], acute nasopharyngitis [14], pertussis, scarlet fever, meningococcal infection [15], outpatient pneumonia [16], functional dyspepsia [17], but medical research of the appointments of asthma pharmacotherapy in children have not been performed before.

\section{Aim of the research}

Carry out a frequency analysis of medicinal prescriptions for pharmacotherapy of asthma in children to increase the availability of pharmaceutical assistance to a certain category of patients.

\section{Materials and methods}

The materials of the study were 574 medical cards of the indoor patient with the main diagnosis of "Bronchial asthma". Patients were treated at the Kyiv City Children's Clinical Hospital No. 2 (duration of the study is January-December 2018). The information collection was performed according to the following key parameters: date, diagnosis, patient (gender and age), medical appointment (trade name, international non-proprietary name, ATC code, dosage form, duration of treatment, number of appointments).

Methods of research: retrospective frequency analysis of the appointments of medicines for archival data of medical cards of inpatient patients, statistical, analytical, and graphic.

\section{Results}

As a result of the analysis of patients by age and sex, it was found that among the total number of patients, 439 were boys $(76.5 \%)$ and 135 were girls $(23.5 \%)$, which corresponds to research data of scholars about sex differences in the prevalence of asthma in children [18-20]. The average age for boys is 11.6 years, and for girls -10.3 . However, the largest number of sick boys was aged 15-16 years, and among girls $-6-8$ years. People of early age (up to 5 years old) had low rates of morbidity, which can be explained by the lack of early diagnosis and the diagnosis of "Bronchial asthma" (Fig. 1). 


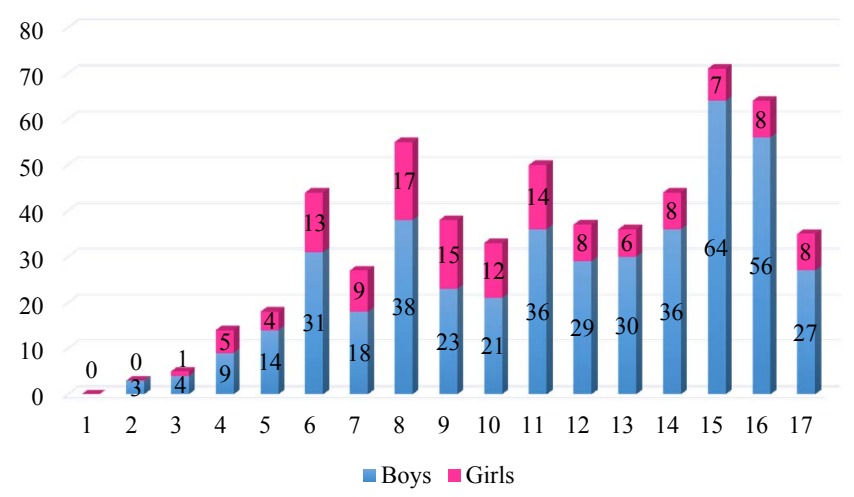

Fig. 1. Sample distribution by gender and age

Also, we analyzed the length of stay of patients in the hospital. Thus, the number of bed days varied from 2 to 51 (the average - 14.2 per 1 patient). In $45.3 \%$, the length of stay was $2-10$ days, and in $37.3 \%-11-20$ days (Table 1). These figures suggest a sufficiently long period of inpatient treatment that affects the overall cost of the disease.

Table 1

Results of the combined analysis of the length of stay of patients on indoor treatment

\begin{tabular}{ccc}
\hline Number of bed days & Number of patients & $\%$ \\
\hline $2-10$ & 260 & 45.3 \\
$11-20$ & 214 & 37.3 \\
$21-30$ & 40 & 7.0 \\
More than 30 & 60 & 10.4
\end{tabular}

In order to evaluate the frequency of use of drugs in the pharmacotherapy of asthma in children, we conducted a frequency analysis of pharmacotherapeutic groups and trade names. According to the letters of appointment in the medical records of the inpatient patient, the physicians carried out 1983 appointments, of which 1867 were medicated (94.2 \%) and 116 were non-medicated methods $(5.8 \%)$.

The medical appointments of doctors included 1763 drugs. Of these, $94.4 \%$ are drugs belonging to 11 groups according to ATC classification, $1.5 \%$ - solutions for washing, irrigation, treatment, $0.3 \%$ - dietary supplements, $0.1 \%$ - homeopathic preparations, $3.7 \%$ - other (Table 2).

Table 2

Frequency analysis of medical prescriptions for the treatment of children with bases of the ATC classification

\begin{tabular}{cccc}
\hline ATC-code & Nomenclature & $\begin{array}{c}\text { Frequency of } \\
\text { prescriptions }\end{array}$ & $\begin{array}{c}\text { \% from the total number } \\
\text { of prescriptions }\end{array}$ \\
\hline A & Alimentary tract and metabolism & 21 & 1.2 \\
B & Blood and blood forming organs & 5 & 0.3 \\
C & Cardiovascular system & 3 & 0.2 \\
D & Dermatologicals & 20 & 1.1 \\
H & Systemic hormonal preparations, excluding sex hormones & 5 & 0.3 \\
J & and insulins & 85 & 4.8 \\
M & Antiinfectives for systemic use & 3 & 0.2 \\
N & Musculo-skeletal system & 9 & 0.5 \\
P & Nervous system & 2 & 0.1 \\
R & Antiparasitic products, insecticides and repellents & 1558 & 88.4 \\
S & Respiratory system & 52 & 2.9 \\
Total & Sensory organs & 1763 & 100
\end{tabular}


According to the data in Table 2, the group R - "Respiratory system" (86.7\%) is in the lead, which needs a more detailed analysis (Tab. 3). It is estimated that the largest number of appointments have subgroups: R01A "Decongestants and other nasal preparations for topical use" (25.2\%), R03A “Adrenergics, inhalants" (24.1\%) and R03B "Other drugs for obstructive airway diseases, inhalants" (20.0\%).

Table 3

Distribution of drugs with frequency of prescriptions in the group "Drugs acting on the respiratory system"

\begin{tabular}{cccc}
\hline ATC-code & Nomenclature & $\begin{array}{c}\text { Frequency of } \\
\text { prescriptions }\end{array}$ & $\begin{array}{c}\text { \% from the total number } \\
\text { of prescriptions }\end{array}$ \\
\hline R01A & Decongestants and other nasal preparations for topical use & 393 & 25.2 \\
R01B & Nasal decongestants for systemic use & 3 & 0.2 \\
R02A & Throat preparations & 18 & 1.2 \\
R03A & Adrenergics, inhalants & 375 & 24.1 \\
R03B & Other drugs for obstructive airway diseases, inhalants & 312 & 20.0 \\
R03D & Other systemic drugs for obstructive airway diseases & 108 & 6.9 \\
R05C & Expectorants, excluding combinations with cough suppressants & 180 & 11.6 \\
R05D & Cough suppressants, excluding combinations with expectorants & 3 & 0.2 \\
R05F & Cough suppressants and expectorants, combinations & 7 & 0.4 \\
R05X & Other cold preparations & 16 & 1.0 \\
R06A & Antihistamines for systemic use & 143 & 9.2 \\
Total & & 1558 & 100
\end{tabular}

According to the results of the frequency analysis of medical cards of indoor patients in the form of trade names of drugs and their international non-proprietary names (INNs), it was established that for their appointments doctors used 187 trade names of medicines that contain 73 INNs.

In order to qualitatively evaluate the number of medicinal prescriptions for each trade name, we calculated the intensity of the appointments $(\mathrm{Ki})$ by the formula

$$
\mathrm{K}_{\mathrm{i}}=\frac{\mathrm{N}}{\mathrm{n}}
$$

where $\mathrm{N}$ - the number of medical cards indoor patients, where a corresponding drug was available; $\mathrm{n}$ - the total number of medical records of a indoor patient.

The indicator of the intensity of appointments characterizes the proportion of patients who received a specific drug and in the study list of the drug, its value varied in a fairly wide range (0.0006 to 0.07$)$. The lowest rates were 70 trademarks of 42 INNs $(37.4 \%)$. Such a large number of drugs with a low intensity of medical appointments are due to the fact that these drugs were used as a pharmacotherapy for concomitant diseases and complications. The highest rates were for only 2 drugs - Ventolin nebuly and Pulmicort, which were available in $22.3 \%$ and $23.0 \%$ of hospitalized patient medical records respectively, that is, every fifth patient.

For a detailed study of the nomenclature of medical prescriptions, the list of trade names was analyzed and by manufacturers. It was found that the ratio of drugs of domestic and foreign manufacture of drugs is $34.2 \%$ (20 pharmaceutical companies) and $65.8 \%$ (25 producer countries) respectively (Fig. 2).

The largest segment of the volume of foreign production, namely $64 \%$, is occupied by 5 countries, such as Great Britain, France, India, Germany and Switzerland. $61 \%$ of the domestic production of the nomenclature of drugs represented in the prescriptions is formed by 5 Ukrainian pharmaceutical companies, namely «Farmak», «Borshchahivskiy CPP», «Kyivmedpreparat», «Pharmaceutical Firm «Darnitsa», «Yuriya-Farm» (Table 4). 


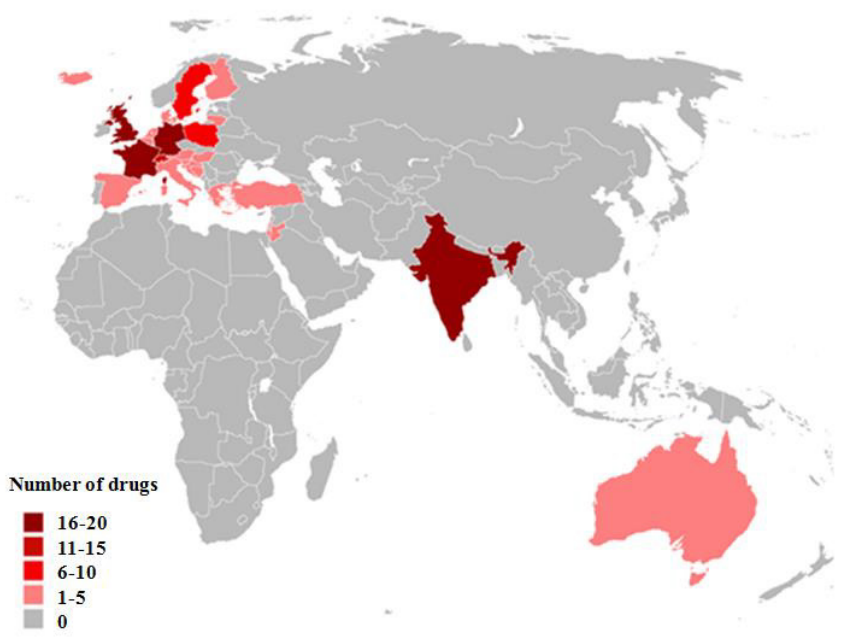

Fig. 2. Cartography of the regions of the world on the level of production of drugs from the nomenclature of medical appointments for 2018

Table 4

Leaders of domestic and foreign manufacture of drugs from the nomenclature of medical prescriptions for children with asthma

\begin{tabular}{cccc}
\hline \multicolumn{1}{c}{ Ukraine } & & \multicolumn{2}{c}{ Other countries } \\
\hline Pharmaceutical company & Number of drugs & Country & Number of drugs \\
\hline «Farmak» & $15(8.0 \%)$ & Great Britain & $18(9.6 \%)$ \\
«Borshchahivskiy CPP» & $8(4.3 \%)$ & France & $18(9.6 \%)$ \\
«Kyivmedpreparat» & $6(3.2 \%)$ & India & $16(8.6 \%)$ \\
«Pharmaceutical Firm & $5(2.7 \%)$ & Germany & $16(8.6 \%)$ \\
«Darnitsa» & $5(2.7 \%)$ & Switzerland & $11(5.9 \%)$
\end{tabular}

The obtained data indicate a promising direction for domestic pharmaceutical companies regarding the development, production and market introduction of drugs used in the treatment of asthma in children.

In view of the fact that in children, the use of drugs can cause certain problems, it becomes necessary to consider the pharmaceutical design of the drug and the feasibility of its use in the target age group. The appropriateness and advantage of different dosage forms varies among children, especially those with asthma. That is why, at the final stage of our study, the medical forms of trade names of drugs were analyzed, which determined the nomenclature of appointments in medical cards of inpatient patients. Leading positions in the assortment were pills (25.4\%), sprays (20.4\%) and solutions (16.8 \%) (Fig. 3).

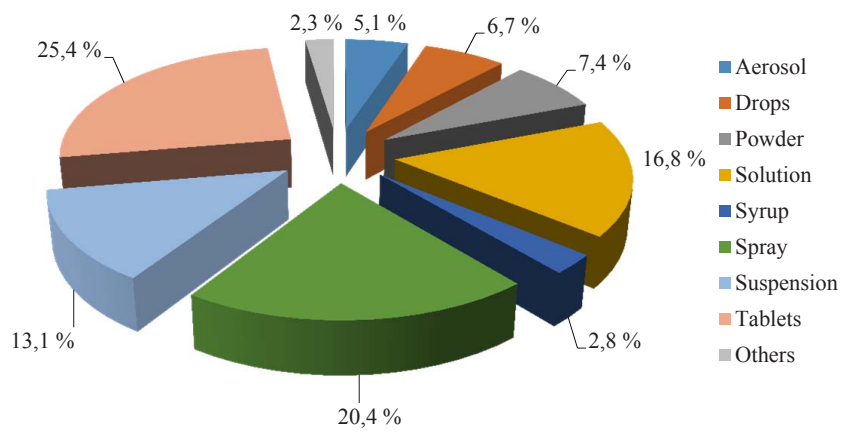

Fig. 3. Distribution of drugs nomenclature according to prescriptions for dosage forms 


\section{Discussion}

The obtained data of the conducted retrospective frequency analysis of the appointments of medical devices on archival data of medical cards of inpatient patients allow establishing a significant nomenclature of medical appointments for asthma in children. A promising direction for domestic pharmaceutical companies in the production of medicines for the treatment of the examined nosology was revealed. At the same time, a frequency analysis of the drug nomenclature can be used in the selection of medicines for reimbursement and medical insurance programs after further pharmacoeconomic studies.

\section{Conclusions}

1. Analysis of the data of medical records of inpatient patients showed that the ratio of male and female patients, namely $76.5 \%$ and $23.5 \%$, respectively, does not differ from the data of previous research on sexual differences in the prevalence of children's asthma. The average age for boys is 11.6 years, and for girls -10.3 .

2. It has been determined that 1983 appointments were made by doctors: the medicinal drugs represented by the drug belonging to 11 groups according to the ATC system $(A, B, C, D, H, J, N$, $\mathrm{M}, \mathrm{P}, \mathrm{R}, \mathrm{S})-94.4 \%$, solutions for washing, irrigation, treatment $-1.5 \%$, dietary supplements $0.3 \%$ and homeopathic preparations $-0.1 \%$, others $-3.7 \%$.

3. It was established that for pharmacological therapy of children's asthma doctors used 187 trade names of drugs, which contain 73 INNs. By the indicator of the intensity of the appointments, 70 trade names of the drug substance 42 INNs were determined, accounting for $37.4 \%$ of the total number of drug nomenclature. Trade names with the highest rates, which include Ventolin nebuly and Pulmicort, were found in the medical card of every fifth inpatient patient.

4. It was investigated that the nomenclature of medical appointments was formed by 26 producing countries, and domestic manufacture of this group of drugs was concentrated in 20 pharmaceutical companies. The most commonly used dosage forms are tablets $(25.4 \%)$, sprays $(20.4 \%)$ and solutions $(16.8 \%)$.

\section{References}

[1] Kanavos, P., Schurer, W., Vogler, S. (2011). The Pharmaceutical Distribution Chain in the European Union: Structure and Impact on Pharmaceutical Prices. London: London School of Economics, 120.

[2] Lenney, W., Bush, A., Fitzgerald, D. A., Fletcher, M., Ostrem, A., Pedersen, S. et. al. (2018). Improving the global diagnosis and management of asthma in children. Thorax, 73 (7), 662-669. doi: http:// doi.org/10.1136/thoraxjnl-2018-211626

[3] Ferreira de Magalhães, M., Amaral, R., Pereira, A. M., Sá-Sousa, A., Azevedo, I., Azevedo, L. F., Fonseca, J. A. (2017). Cost of asthma in children: A nationwide, population-based, cost-of-illness study. Pediatric Allergy and Immunology, 28 (7), 683-691. doi: http://doi.org/10.1111/pai.12772

[4] Pro zatverdzhennia ta vprovadzhennia medyko-tekhnolohichnykh dokumentiv zi standartyzatsii medychnoi dopomohy pry bronkhialnii astmi (2013). Nakaz MOZ Ukrainy vid 08.10.2013 No. 868. Available at: https://zakon.rada.gov.ua/rada/show/v0868282-13

[5] Osnovy zakonodavstva Ukrainy pro okhoronu zdorovia (1992). Zakon Ukrainy vid 19.11.1992 No. 2801-XII. Available at: https://zakon.rada.gov.ua/laws/show/2801-12

[6] Pro zatverdzhennia Kontseptsii rozvytku farmatsevtychnoho sektoru haluzi okhorony zdorovia Ukrainy na 2011-2020 roky (2010). Nakaz MOZ Ukrainy vid 13.09.2010. No. 769. Available at: https://zakon. rada.gov.ua/rada/show/v0769282-10

[7] Piniazhko, O. B. (2016). Analiz realnykh danykh pryznachen likarskykh zasobiv pry poshyrenykh hinekolohichnykh zakhvoriuvan v Ukraini. Farmatsevtychnyi zhurnal, 3-4, 29-41.

[8] Mishchenko, O. Ya., Yakovlieva, L. V., Ostashko, V. F. (2016). Rezultaty chastotnoho analizu pryznachen likarskykh zasobiv khvorym na ishemichnu khvorobu sertsia yak kryterii otsinky yakosti farmakoterapii. Klinichna farmatsiia, 4, 24-28.

[9] Yakovlieva, L. V., Mishchenko, O. Ya. (2016). Kliniko-ekonomichnyi analiz farmakoterapii khvorykh na liushboishialhiiu. Ratsionalna farmakoterapiia, 2, 19-24. 
[10] Zaiats, M. M., Zimenkovskyi, A. B. (2013). Kliniko-ekonomichnyi analiz yak skladova optymizatsii farmakoterapii metabolichnoho syndromu. Zaporizkyi medychnyi zhurnal, 4, 10-12.

[11] Masheiko, A. M., Makarenko, O. V., Mavrutenkov, V. V. (2016). Kliniko-ekonomichnyi analiz vytrat na farmakoterapiiu hostroho tonzylitu v umovakh statsionaru. Farmatsevtychnyi chasopys, 41, 48-53. doi: http://doi.org/10.11603/2312-0967.2016.4.7121

[12] Tkachova, O. V., Silaiev, A. O. (2016). Kliniko-ekonomichnyi analiz farmakoterapii khvorykh na khronichnyi kholetsystyt. Upravlinnia, ekonomika ta zabezpechennia yakosti v farmatsii, 1, 80-85.

[13] Nemchenko, A. S., Balynska, M. V. (2016). Rezultaty kliniko-ekonomichnoho analizu spozhyvannia likarskykh preparativ khvorym dytiachoho viku na virusnu diareiu. Upravlinnia, ekonomika ta zabezpechennia yakosti $v$ farmatsii, 3, 60-67.

[14] Tkachova, O. V., Silaiev, A. O. (2016). Kliniko-ekonomichnyi analiz farmakoterapii ditei z hostrym nazofarynhitom. Sotsialna farmatsiia v okhoroni zdorovia, 3, 75-82.

[15] Fediak, I. O. (2014). Rezultaty kliniko-ekonomichnoho analizu farmatsevtychnoho zabezpechennia ditei z kashliukom, skarlatynoiu, meninhokokovoiu infektsiieiu. Klinichna farmatsiia, 18 (1), 29-34.

[16] Bieliaieva, O. I. (2012). Kliniko-ekonomichni kharakterystyky farmakoterapii poza likarnianoi pnevmonii u ditei. Farmatsevtychnyi chasopys, 4, 163-168.

[17] Gerasymova, O. O., Meshcheryakova, I. V. (2017). Clinical and economic analysis of the pharmacotherapy in children with functional dyspepsia. Clinical pharmacy, 21 (1), 19-24. doi: http://oi. org/10.24959/cphj.17.1415

[18] Pro zatverdzhennia ta vprovadzhennia medyko-tekhnolohichnykh dokumentiv zi standartyzatsii medychnoi dopomohy pry bronkhialnii astmi (2013). Nakaz MOZ Ukrainy vid 08.10.2013. No. 868. Available at: https://zakon.rada.gov.ua/rada/show/v0868282-13

[19] Bilak, V. M., Chonka, Ya. V., Bilak, I. D. (2013). Stan reaktyvnosti bronkhiv u ditei, khvorykh na bronkhialnu astmu, pid vplyvom likuvannia metodom speleoterapii. Problemy klinichnoi pediatrii, 3, 14-17.

[20] Maidannyk, V. H., Smiian, O. I. (2017). Bronkhialna astma u ditei. Sumy: Sumskyi derzhavnyi universytet, 243 . 